\title{
INSTITUTIONAL PRESSURES, LEGITIMACY, RISKS, UNCERTAINTY AND VOLUNTARY ADOPTION OF IFRS FOR SMES IN VIETNAM
}

\author{
Trinh Hiep Thien \\ School of Accounting, University of Economics Ho Chi Minh City, Ho Chi Minh City, Vietnam \\ Nguyen Xuan Hung \\ School of Accounting, University of Economics Ho Chi Minh City, Ho Chi Minh City, Vietnam
}

\begin{abstract}
The purpose of this study was to determine the impact of institutional variables, risks, and dependence on the voluntary application of international financial reporting standards. The study used a quantitative research method based on regression analysis, with data obtained from a survey from among Vietnam's small and medium businesses. The findings confirmed that legitimacy, dependence, consistency, time, international trade, uncertainty, operational risk, financial risk, and industry all have a positive impact on the ability to voluntary application international financial reporting standards, with the exception of flexibility, which has a negative impact. The findings of the study have consequences for stakeholders in making proper policy decisions about the application of the International Financial Reporting Standards.
\end{abstract}

Keywords: institutional iressures, legitimacy, risks, uncertainty, voluntary adoption of International Financial Reporting Standards

DOI: http://dx.doi.org/10.15549/jeecar.v8i4.744

\section{INTRODUCTION}

As of 2021, 132 nations around the world have adopted International Financial Reporting Standards (IFRS). IFRS is a set of internationally recognized accounting standards drafted and developed by the International Accounting Standards Board (IASB), which provides highquality accounting information and recommends strict accounting rules. When IFRS was adopted widely over the world, the presentation of financial statements based on IFRS standards increased transparency and enhanced accounting comparability. The Ministry of Finance of the Government of Vietnam has a specific plan to adopt the IFRS in Vietnam through the revision of the Vietnamese Accounting Standards (VAS). The preparation period is from 2019 to the end of 2021, followed by a voluntary application period between 2022 and the end of 2025. Firms have to use IFRS after 2025.

Research related to the process of adopting IFRS in some nations was done by Odia (2016) and Paknejad (2017). According to research done 
by Pham Thi Hong Duc (2014), the actual situation of applying IFRS in Vietnam was meeting some difficulties such as an economy that is in transition and a small level of the development of its economy and capital market. As a result, there was not enough data to meet the requirements of international financial reporting standards. In addition, the presentation of financial statements based on IFRS requires a high level of expertise that was not yet present in Vietnam (limited knowledge and experience is a major barrier when applying IFRS), the legal system was not yet able to apply IFRS, and domestic investors were not sufficiently prepared to be able to use financial statements presented following IFRS to make their economic decisions.

The expectations and aims that support companies becoming more conformable to social standards and more efficient in their operations by intensifying the demands of conformity are referred to as institutional pressure. (Oliver, 1991, Guerreiro, Rodrigues \& Craig, 2012).

The implementation of harmonized accounting standards improves the comparability of commonly used financial statements, makes financial statements easier to read and understand, and improves investment decisionmaking efficiency. The implementation of the International Financial Reporting Standards (IFRS) is the result of a process of greater harmonization, which has significant ramifications for developing countries. The application of IFRS might be optional or mandatory. The process of implementing IFRS, on the other hand, is quite costly because it necessitates reorganizing the existing accounting system. As a result, the lack of human resources and capital required to implement it creates challenges for small and medium-sized businesses. Indeed, the shift to IFRS is more than just a bookkeeping exercise and the transition to IFRS is more than just an accounting exercise; it has ramifications across the board, including governance, financial management, and internal control.

There are limited studies on the impact of institutional pressure on voluntary choice during the deployment of IFRS, particularly in developing countries. Furthermore, due to the significant amount of resources available, studies applying IFRS to large or publicly traded organizations is simpler to conduct than it is for small and medium-sized businesses. As a result, this study investigated the impact of institutional pressure factors on the decision to use IFRS in small and medium-sized businesses. In addition, it looked into some specific aspects of the Vietnamese setting that were discussed in prior research, so the findings can be used as a foundation for future research.

\section{LITERATURE REVIEW}

The fundamental theories used in the study were derived from previous research and include decision usefulness theory, institutional theory and legitimacy theory (Guerreiro et al., 2012). Economic interests, government functions, and social expectations were all used in these theories to describe the link between concepts.

\section{Institutional theory}

Economic, legal, cultural, and political groupings are the four categories identified by institutional theory. This theory addresses the role of polities, including government authority, professional organizations, and society, to establish the behavior of companies. Scott (2004) showed that companies have little choice, so most companies have to abide by the requirements of government policies when the government implements IFRS. Meyer and Rowan (1977) investigated the impact of institutional pressure on a company that operates in a similar industry. The findings demonstrated that institutional pressures are realized through social norms and state regulations. When companies do business, they have to comply with economic institutions, which are the legal provisions and laws (Le and Hoang, 2017).

\section{Decision usefulness theory}

This theory comes from the nature of accounting, which provides information useful to help the users make the right decisions. That also means information presented in financial statements can help users review the past and predict the company's future. Thus, it is necessary to present true and fair accounting information, and it must reflect the nature of the 
arising economic transactions (Hitz, 2007; Dandago, and Hassan, 2013).

\section{Legitimacy theory}

Legitimacy theory shows that companies have to comply with the provisions of current laws when the conduct businesses in a country as a way to meet the expectations of society and enhance the value and image of the company. Through the theory of legitimacy, companies are motivated to make decisions using more standards. Thus, it is possible to understand the factors of legitimacy theory that influence these decisions of the company (De Luca, \& PratherKinsey, 2018).

For Guerreiro et al. (2012), institutional theory explained the reason for the voluntary application of IFRS, which emphasizes the interests, identity, values, and assumptions of individuals and organizations. The results show that legitimacy is a strong factor influencing voluntary IFRS adoption. Parent companies and subsidiary companies easily IFRS to help make financial statements more comparable. A business environment that has many risks also is a factor encouraging the voluntary application of IFRS, as it will increase the trust of third parties in the financial statements. Moreover, a company that is in a similar industry or in the same field of activity can affect the decision to accept the use of or comply with IFRS. The research believes that the decision to accept international standards relates to a developing country's institutional factors such as the progress of the economy and current legal regulations. According to Svensson and Saga (2015), the owners of the foreign company have a desire to choose to use a higher quality accounting by adopting the international accounting framework. Thus, the owner's desire to gain quality information from financial accounting is a major factor in the selection of adopting the framework. Following Bassemir (2018), research shows that enterprises with large private capital, many subsidiaries, and many international transactions are more inclined to choose IFRS. Information is more complex, and adopting IFRS standards are more necessary to reduce any asymmetric information. Furthermore, the research expected net profit using IAS to vary significantly across groups of private companies, depending on the management needs and financial accounting information needs. Specifically, private companies using IFRS have more growth opportunities and international activities and have better external factors such as attractive capital or being listed on the stock exchange.

Following Guerreiro et al. (2012), organizations subject to institutional pressures such as expectations or intended goals to achieve benefits and operate efficiently pursue conformity to societal requirements and mainstream recognition,. Firms are willing to accept institutional compliance under institutional pressures, which may also be understood as a response that businesses utilize to gain societal acceptability and increase their legitimacy (Meyer \& Rowan, 1977; Oliver, 1991; Phan, Joshi \& Mascitelli, 2018; Guerreiro, Lima Rodrigues \& Craig, 2021). There are arguments about alternatives that raised the voluntary acceptance of international financial reporting standards by enterprises, which is related to the fact that enterprises have large resources. The institutional theory also provides additional insights into the causes of this firm choice of willing behavior. For example, firms apply IFRS to legitimize their legitimacy (Dillard, Rigsby, \& Goodman, 1991), and those that use IFRS as a support system for their official image can announce their commitment to legal behavior, giving the business more legitimacy (Han, 2020). Over time, these firms got used to IFRS and it became part of their operations. Thus, enterprises will tend to be more willing to accept IFRS. We propose the following research hypothesis based on the preceding arguments:

Hypothesis 1: Legitimacy has a positive impact on the voluntary adoption of IFRS.

According to Oliver (1991), the more diversity is in an organization's composition and the lower the degree of external dependency, the greater the likelihood of the occurrence of institutional forces and its ability to resist them. The parent firm (Guerreiro et al., 2012, Albu, Albu \& Alexander,2014), investors/shareholders, the state, auditors, as well as internal components, have all been discussed in relation to IFRS ( Zelinschi, Levant, Berland, 2012). One of the most important external dependencies is reliance on financial resources from credit institutions or 
shareholders. This dependence is especially important for subsidiaries because the subsidiary is financially dependent on the parent company. Multinational corporations often want to apply IFRS because it makes the consolidation of financial information easier and can control the exchange of resources easier and at a lower cost (Palmer, Jennings, \& Zhou, 1993). Accordingly, subsidiaries tend to apply IFRS to operate effectively and, most importantly, to comply with decisions from the parent company, with the expectation that the accounting data has the same recognition standards as that of the parent company. However, if the application of IFRS is not in the interests of the subsidiary, it will provide reasonable reasons for refusing to apply it.

Hypothesis 2: Dependence has a positive impact on the voluntary adoption of IFRS.

Oliver (1991) found that when institutional pressures or expectations are consistent with corporate goals, the organization chooses to respond with a more willing attitude to accommodate that expectation. When subsidiaries or dependent accounting organizations are no longer consistent with the parent company, corporations begin to doubt the legitimacy of these subsidiaries. This inconsistency arises when organizational goals are fragmented, containing many factors that increase the fragmentation of initial orientations and weaken the legitimacy of the business (Meyer \& Rowan, 1977). The difference in the management form of the subsidiary, as well as the difference in social culture, also increases the deviation in as well as the general orientation of the whole corporation. Therefore, companies that are subsidiaries or are financially dependent from the parent company need to determine the effectiveness of accounting to harmonize financial information in the group. In multinational companies or large corporations, IFRS is recognized as a set of high-quality accounting standards that are highly transparent and in line with international practices. Parent companies that are international corporations or multinational companies tend to plan to have their subsidiaries issue shares on the stock market to raise more capital from it (Mantzari, Sigalas, \& Hines, 2017). The quick application of IFRS will help organizations easily obtain a legal image as well as easily determine the capacity of the accounting system. Because subsidiaries are controlled by the parent company, it believes that applying IFRS standards will help reduce consolidation, distribution and control, and improve resource allocation (Mantzari et al., 2017; Albu, Albu \& Gray, 2020).

Hypothesis 3: Consistency has a positive relation to the voluntary adoption of IFRS.

IFRS requires disclosure and accounting method choices that managers are adopting more than the national set of accounting standards. Therefore, the switch to applying IFRS limits the decision-making of accounting management and affects the internal interests of enterprises. Furthermore, the application of international financial reporting standards also implies a greater change in the culture and perception rules of appropriateness in accounting (Tokar, 2005). IFRS also has many differences compared to the current accounting regulations and requires a higher level of accounting personnel and higher reporting quality requirements. This leads to an increase in workload and requires more investment from those who do the reports, particularly because IFRS is written in English (Guerreiro et al. al., 2012; Guerreiro et al., 2021).

Hypothesis 4: The flexibility of international financial reporting standards has a positive correlation with the voluntary of adoption IFRS.

Following Oliver (1991), if institutional rules or standards are widely disseminated, firms are more likely to comply. Moreover, institutionalization occurs when it becomes common and provides a greater sense of legitimacy, leading firms to more likely adapt to institutionalization pressures (Thornton and Ocasio, 1999). IFRS is accepted and becomes a worldwide trend because firms and authority consider it as the relevant organizational standard (Guerreiro et al., 2012, Mantzari et al., 2017).

Hypothesis 5: The acceptance of IFRS in the world through international trade has a positive impact on the voluntary adoption of IFRS.

Oliver (1991) noted that a firm's business strategists prefer stability and control; a company that has an operational plan based on a stable environment achieves its business goals. 
As a result, uncertainty in business makes the methods that are used to achieve results uncontrollable and hinders the firm's strategy (Lowe, 2000). Thus, when firms face high environmental uncertainty, they tend to accept institutional pressure to protect themselves from environmental disturbances (Meyer and Rowan, 1977). Such instability comes from two main sources - the environment (external sources), and the organization's tasks and business plans (internal sources). Guerreiro et al. (2012) hypothesized that there are three main types of instability considered as institutional pressures affecting the decision to adopt voluntary IFRS: instability in the external environment; the instability of the enterprise's operations; and the instability of financial factors. Adopting highquality accounting standards such as IFRS can help companies cope with an uncertain environment. According to Thompson (1967) when there is uncertainty or dispute, the accounting system promotes the values and official position of the organization.

Hypothesis 6: Uncertainty in the business has a positive impact on the voluntary adoption of IFRS.

According to institutional theory, the stronger the ties between companies in an industry, the more widely standards are communicated and institutional compliance is encouraged (Oliver, 1991). In a highly linked context, norms are dispersed through ostensible links in order to reach consensus, which can lead to the greater spreading of institutional effects. Strong crosssector alliances encourage enterprises to be better prepared to respond to institutional demands, as they band together to create collective identity and function as a conduit for institutional arguments. When collective identities are institutionalized, they have their own institutional reasoning, which influences and develops rules of behavior for group member organizations (Guerreiro et al., 2012; Albu et al., 2014).

Hypothesis 7: The level of connectivity in an industry when applying IFRS has a positive relationship with the voluntary adoption of IFRS.

\section{METHODOLOGY}

Primary data was collected by the author through survey research in Vietnam. The total number of questionnaires sent (online and offline) was 400 , and the total number of accepted and fully informed survey questionnaires was 272. It was sent to people with knowledge of IFRS who are auditors, financial directors, or chief accountants working at a Vietnamese company with private capital that have not yet been listed, and also masters students and experts with a clear understanding of international financial reporting standards. The survey was distributed and collected from October to November 2019 through dicrect survey questions and indirect as mail, social networks, and accounting forums.

\section{Model}

The research model is presented as follows:

$$
\begin{aligned}
& \text { IFRS }_{i}=\delta_{1} \text { Legitimacy }_{i}+\delta_{2} \text { Dependence }_{i} \\
&+\delta_{3} \text { Consistency }_{i}+\delta_{4} \text { Time }_{i} \\
&+\delta_{5} \text { Flexibility }_{i}+\delta_{6} \text { Trade }_{i} \\
&+\delta_{7} \text { Uncertainty }_{i} \\
&+\delta_{8} \text { Operational Risks }_{i} \\
&+\delta_{9} \text { Financial Risk }_{i} \\
&+\delta_{10} \text { Industry }_{i}+\varepsilon_{i}
\end{aligned}
$$

Where:

IFRS is a symbol that represents the measurement of the concept of the voluntary application IFRS. Following Oliver (1991), the survey questionnaire was conducted and applied according to Oliver's model with the 5 institutional premises proposed by Oliver as the independent variables. A Likert scale was used to assess the variables along the factors that are hypothesized to have an impact on the voluntary application of IFRS. The dependent variable is the ability to apply IFRS voluntarily. This dependent variable is measured by a nominal scale according to (Guerreiro et al., 2012) who surveyed enterprises which voluntarily applied IFRS.

Legitimacy: This variable was measured in the survey through a set of 4 questions about whether the application of IFRS increases prestige and meets international trends. (Phan et al., 2018)

Dependence : Using a proposal from Guerreiro et al. (2012), this variable was tested using an identifier that had the symbol " 1 " if the firm is a 
subsidiary of a multinational company, and " 0 " otherwise.

Consistency: This variable shows consistency with parent company goals and was given a " 1 " if the parent company is an international listed company, otherwise " 0 ".

Time: This variable shows the time to adopting the new standard. It was measured using a survey question asking when is the right time to apply it (Phan, 2014).

Flexibility: This variable shows the flexibility of the new standard and was measured following a proposal of Phan (2014) through a survey on whether enterprises have a lot of autonomy and convenience to meet the requirements when applying the new standard.

Trade: This scale is measured through a survey question on the level of international transactions that was taken from the study of Svensson and Saga (2015).

Uncertainty: This variable show the uncertainty in the business. Measured as suggested by (Gordon and Narayanan, 1984) with the survey by the uncertainty of the business environment.
Operational Risks: Survey measurement of business instability of enterprises through questionnaires inherited from the research of Radomska (2014).

Financial Risks: According to Abor and Biekpe (2006), the financial risk variable is measured through a survey on the difficulty of accessing external capital of enterprises.

Industry: Measured according to the proposal of Svensson and Saga (2015), whereby a survey was conducted on the impact of external factors in the field the business is operating.

All the specific scales of the independent and dependent variables in the model are presented in Appendix 1 with detailed survey questions.

\section{DISCUSSION}

Descriptive statistics on sample data in Table 1 show that there are 272 enterprises in the analysis consisting of 179 non-manufacturing enterprises accounting (65.8\%) and 93 manufacturing enterprises (34.2\%). The vast majority, $93.7 \%$, of the survey subjects have bachelor's and master's degrees, which provides a good foundation for the response quality.

Table 1: Descriptive statistics on survey participants' personal information

\begin{tabular}{|l|l|l|l|}
\hline \multirow{2}{*}{ Division } & Frequency & $\begin{array}{l}\text { Percent of the } \\
\text { total sample }\end{array}$ \\
\hline \multirow{2}{*}{ Business fields } & Non-Manufacturing & 179 & 65.8 \\
\cline { 2 - 4 } & Manufacturing & 93 & 34.2 \\
\hline \multirow{5}{*}{ Education } & & & \\
\hline \multirow{5}{*}{ Experience } & College & 9 & 3.3 \\
\cline { 2 - 4 } & Bachelor & 151 & 55.5 \\
\cline { 2 - 4 } & Master & 104 & 38.2 \\
\cline { 2 - 4 } & Asociate & 8 & 2.9 \\
\hline & & 16 & 5.9 \\
\hline & $16-20$ years & 211 & 77.6 \\
\cline { 2 - 4 } & $6-10$ years & 45 & 16.5 \\
\cline { 2 - 4 } & Less than 5 years & & \\
\hline
\end{tabular}

Source: author's data analysis

Because chief accountants, finance directors, and general accountants, all of whom have a good understanding of IFRS, participated in the survey, the results may be trusted. In addition,
$83.5 \%$ of survey respondents have six or more years of work experience and therefore are good judges of IFRS and its importance. 
Table 2: Cronbach's Alpha coefficient for independent variables

\begin{tabular}{|c|c|c|c|}
\hline Items & $\begin{array}{l}\text { Scale Mean if Item } \\
\text { Deleted }\end{array}$ & $\begin{array}{l}\text { Scale Variance if Item } \\
\text { Deleted }\end{array}$ & $\begin{array}{l}\text { Corrected Item Total } \\
\text { Correlation }\end{array}$ \\
\hline \multicolumn{4}{|c|}{ Legitimacy: $\alpha=0.728$} \\
\hline LEGITIMACY1 & 11.89 & 4.789 & 0.492 \\
\hline LEGITIMACY2 & 11.49 & 4.679 & 0.649 \\
\hline LEGITIMACY3 & 11.80 & 4.789 & 0.447 \\
\hline LEGITIMACY4 & 11.66 & 4.852 & 0.505 \\
\hline \multicolumn{4}{|l|}{ Time: $\boldsymbol{\alpha}=0.795$} \\
\hline TIME1 & 3.38 & 1.431 & 0.661 \\
\hline TIME2 & 3.31 & 1.256 & 0.661 \\
\hline \multicolumn{4}{|c|}{ Flexibility: $\alpha=0.721$} \\
\hline FLEXIBILITY1 & 20.37 & 7.887 & 0.554 \\
\hline FLEXIBILITY2 & 20.15 & 9.442 & 0.426 \\
\hline FLEXIBILITY3 & 20.39 & 8.978 & 0.347 \\
\hline FLEXIBILITY4 & 20.28 & 8.785 & 0.357 \\
\hline FLEXIBILITY5 & 20.11 & 8.575 & 0.448 \\
\hline FLEXIBILITY6 & 20.33 & 7.168 & 0.620 \\
\hline \multicolumn{4}{|l|}{ Trade: $\alpha=0.724$} \\
\hline TRADE2 & 1.48 & .634 & 0.697 \\
\hline TRADE3 & 2.12 & 2.392 & 0.697 \\
\hline \multicolumn{4}{|c|}{ Uncertainty: $\alpha=0.825$} \\
\hline UNCERTAINTY1 & 14.70 & 9.664 & 0.706 \\
\hline UNCERTAINTY2 & 14.68 & 9.002 & 0.760 \\
\hline UNCERTAINTY3 & 14.66 & 9.931 & 0.703 \\
\hline UNCERTAINTY6 & 14.62 & 9.107 & 0.738 \\
\hline UNCERTAINTY7 & 14.77 & 9.005 & 0.728 \\
\hline \multicolumn{4}{|c|}{ Operational risks: $\alpha=0.794$} \\
\hline OR1 & 4.11 & .445 & 0.670 \\
\hline OR4 & 4.07 & .651 & 0.670 \\
\hline \multicolumn{4}{|c|}{ Financial risks: $\alpha=0.805$} \\
\hline FR1 & 20.54 & 27.954 & 0.575 \\
\hline FR2 & 20.48 & 27.513 & 0.584 \\
\hline FR3 & 20.83 & 27.932 & 0.619 \\
\hline FR4 & 20.75 & 29.168 & 0.505 \\
\hline FR5 & 20.29 & 29.699 & 0.484 \\
\hline FR6 & 21.01 & 30.491 & 0.403 \\
\hline FR7 & 20.96 & 29.854 & 0.400 \\
\hline FR8 & 20.84 & 27.885 & 0.570 \\
\hline \multicolumn{4}{|c|}{ Industry: $\alpha=0.852$} \\
\hline INDUSTRY2 & 3.16 & 1.130 & 0.743 \\
\hline INDUSTRY3 & 3.03 & 1.132 & 0.743 \\
\hline
\end{tabular}

Source: author's data analysis.

\section{Legitimacy}

This factor is measured by four observed variables, with a Cronbach's Alpha coefficient of 0.728 . Because is greater than 0.6 , it is considered appropriate and reliable. Moreover, the total correlation coefficient of the four observed variables is greater than 0.3 , so they are satisfied as well. 


\section{Time}

The Time factor is measured by two observed variables, and the Cronbach's Alpha coefficient is 0.795, again indicating that it is suitable and reliable. Furthermore, the total correlation coefficient of TIME1 and TIME2 is greater than 0.3 , indicating that TIME1 and TIME2 are adequate.

\section{Flexibility}

The Flexibility factor is measured by ten observed variables; however, four of them are included in the step of calculating the total correlation coefficient. Therefore, the six observed variables of this factor are satisfied and reliable.

\section{International trade}

Three observed variables are used to calculate the International Trade factor. Following the removal of this observed variable from the analysis data, the sum of the Cronbach's Alpha coefficients of the two observed variables is 0.724 , and the total of the correlation coefficients of these variables is greater than 0.3

\section{Uncertainty}

After the removal of two unsatisfied observed variables for the Uncertainty factor, the Cronbach's Alpha coefficient for the five remaining observed variables is 0.886 , and the total correlation system is greater than 0.3 . The conclusion is that these observed variables are qualified and reliable enough to measure.

\section{Operational risks}

After removing OR2 and OR3, the Cronbach's Alpha coefficient of the remaining two observed variables for this factor is 0.794 and the total correlation coefficient of OR1 and OR4 is greater than 0.3 , showing that the remaining two observed variables are eligible for measurement.

\section{Financial risks}

The Financial risks factor is measured by eight variables, with the Cronbach's Alpha coefficient at 0.805; thus, it is considered appropriate and reliable. Besides, the coefficients are greater than 0.3 , so all eight variables are satisfied.

\section{Industry}

After removing the unsuitable INDUSTRY1 and re-testing, the Cronbach's Alpha coefficient of the remaining two variables for the Industry factor is 0.852 and the total correlation coefficient is greater than 0.3 . The conclusion is that these observed variables are qualified and reliable enough to measure.

Table 3: Analysis of regression results

\begin{tabular}{|c|c|c|c|c|c|c|}
\hline Variables & Coefficient & $\begin{array}{c}\text { Standard } \\
\text { Error }\end{array}$ & Wald & df & P-value & Exp(B) \\
\hline DEPENDENCE & 0.658 & 0.371 & 1.850 & 1 & 0.035 & 1.710 \\
\hline CONSISTENCY & 1.526 & 0.565 & 7.283 & 1 & 0.007 & 4.598 \\
\hline UNCERTAINTY & 0.212 & 0.200 & 1.129 & 1 & 0.028 & 1.236 \\
\hline FINANCIAL RISKS & 0.086 & 0.167 & 1.267 & 1 & 0.006 & 1.090 \\
\hline FLEXIBILITY & -0.749 & 0.286 & 6.859 & 1 & 0.009 & 1.473 \\
\hline LEGITIMACY & 1.107 & 0.271 & 16.757 & 1 & 0.000 & 3.026 \\
\hline OPERATIONAL RISKS & 0.880 & 0.211 & 1.325 & 1 & 0.009 & 1.887 \\
\hline TRADE & 0.419 & 0.147 & 8.162 & 1 & 0.004 & 1.521 \\
\hline TIME & 0.903 & 0.141 & 1.468 & 1 & 0.049 & 1.908 \\
\hline INDUSTRY & 0.516 & 0.167 & 8.442 & 1 & 0.004 & 1.616 \\
\hline Constant & -1.370 & 1.682 & 14.048 & 1 & 0.006 & 0.006 \\
\hline
\end{tabular}

Source: author's data analysis. 
In the rotated factor matrix, the observed variables are focused on each factor more clearly, and the observed variables have factor loading coefficients above 0.5 except for 2 variables, FR6 and FR7; these will not be used in the following analysis.

Omnibus tests of model coefficients show that the sig values of the 3 steps, block, and model indexes are 0.000 lower than 0.05 , so the regression model is statistically significant and can explain the impact of the independent variables on the dependent variable. In 107 "not adopting" observations, 41 "not applicable" cases are predicted; the correct prediction rate is 38.3\%. In 165 "adopting" observations, 138 "adopting" cases are predicted, and here the correct prediction is $83.6 \%$. The correct prediction rate of the whole model is $65.8 \%$. In the summary results of the model, the parameter -2 Log likehood is 126,031 which is not too high, which means that the model used for analysis is suitable.

Wald test results are used to check whether the independent variable is significant in the regression model or not. The Sig value of Wald test shows that all the independent variables are less than 0.05 , meaning the confidence level is above $95 \%$, so ten independent variables have an influence on the voluntary decision to adopting IFRS.

To solve the research objectives, logit regression findings were used to examine the correlation between the independent factors and the dependent variable. Following the scale tests, we used Logit regression. The regression coefficients (B) of the independent variables are all positive, that is, the independent variables all have a positive effect on the dependent variable, except for "flexibility" which has a negative value, which means that it will have a positive effect if the coefficient moves in the opposite direction to the dependent boundary.

Accordingly, the Binary Logistic regression equation shows the relationship between the dependent variable and the independent variables as follows:

Ln $\left(\frac{P(I F R S=1)}{P(I F R S=0)}\right)=1.107$ LEGITIMACY +0.658 DEPENDENCE + 1.526CONSISTENCY + 0.903 TIME - 0.749 FLEXIBILITY + 0.419 TRADE + 0.212 UNCERTAINTY + 0.88 OPERATIONAL RISKS +

\subsection{FINANCIAL RISKS + 0.516 INDUSTRY -1.37}

Where "Consistency" is the most influential with a regression coefficient of 1.526. The variables "Legitimacy" and "Time" with regression coefficients of 1.107 , and 0.903 , respectively. While Operational risk" with a regression coefficient of 0.88 , and "Dependence" with a regression coefficient of 0.658 . "Industry" and "International trade" with a regression coefficient of 0.516 , and 0.419 , respectively. The variable "Uncertainty" has a regression coefficient of 0.212 , and the lowest is "Financial risk" with a regression coefficient of 0.086 . In contrast, the variable "Flexibility" has a regression coefficient of -0.749 .

This result shows that when enterprises face different institutional pressures, the response level of enterprises to the voluntary application of IFRS is also different, and this level corresponds to the regression coefficient.

Through the research results, at the step of testing the reliability of the scale and analyzing the EFA, the research filtered the observed variables that are suitable for the model and identified the factors that affect the voluntary application of IFRS. Binary Logistic regression analysis helps to determine the degree of influence of each factor on the voluntary application of IFRS.

The variable Consistency represents the consistency of the target of the parent company; this variable has the strongest influence on the choice of voluntary IFRS application. The results are consistent with the research of Guerreiro et al. (2012) which showed that the target of the parent company affects the accounting work. Subsidiaries are willing to accept regulations from the objective business group, or regulations from the parent company.

The formal pursuit of legitimacy also has a strong impact on the voluntary adoption of IFRS. This research result is also consistent with the study of Guerreiro et al. (2012) and Guerreiro et al. (2021) . The results show that the voluntary application of IFRS as a set of prestigious and highly recognized standards helps businesses improve their image of social legitimacy.

Time is also a factor affecting the voluntary application of IFRS, and the results of this study are similar to those of Phan (2014). When there 
is enough time to prepare for the transition from VAS to IFRS, voluntary adoption will be easier, but the process also requires the coordination of Vietnamese authorities.

Operational risk has an impact on the voluntarily adoption of a new set of standards. Following Radomska (2014), when the effectiveness of the implementation of strategic goals have a negative effect on operational risks from the environment and people, it is necessary to have a standard to systematically evaluate and supervise the accounting work of enterprises. Therefore, choosing to apply a set of accounting standards with high quality and strict requirements like IFRS is an appropriate choice.

The Dependency factor is also a factor that affects the willingness to apply IFRS (Guerreiro et al., 2012, Mantzari et al., 2017; Albu et al., 2020). When companies are subsidiaries of a multinational company, it is necessary to adopt IFRS, which helps financial reporting to be more transparent and shows compliance with the requirements of the parent company.

The Industry factor has an impact on the voluntary decision to apply IFRS (Goodstein, 1994). Connecting businesses in the same industry will promote collectivism and consensus in the application of IFRS. Once the company connects with other companies in the industry, there are many opportunities to access information and broaden opportunities for cooperation as well as promote the exchange and development of the company in the industry.

International trade is a factor that affects the willingness to apply new standards to enterprises (Guerreiro et al., 2012). The higher the popularity of IFRS, the higher the degree of the voluntary adoption of IFRS, which shows that the cohesion of the application of IFRS as well as the accounting work of enterprises is also widely recognized.

Uncertainty is the factor influencing the voluntary adoption of IFRS. When businesses face economic uncertainty, it is necessary to have quality information. Therefore, economic and financial information plays an important role in businesses to support their decision-making. Following Gordon, \& Narayanan (1984), the application of IFRS helps businesses meet the demand for high-quality information for decision-making.
Financial risk is also a factor that has a positive effect on the voluntary application of IFRS (Abor \& Biekpe, 2006). When firms face financial uncertainties, it is necessary to have high-quality financial statements and accurate financial information. This helps the company to access external financial sources from third parties by supplying high-quality financial reporting.

The flexibility of IFRS also has an impact on the voluntary adoption of IFRS. However, this result is contrary to the original hypothesis (Phan, 2014). The results of this study are based on surveyed variables. When the flexibility of applying IFRS is not high, it causes difficulties in the accounting work of enterprises, although the research results show that other factors such as Consistency and compliance with Legitimacy have a positive impact on the application of international financial reporting standards.

\section{CONCLUSION AND RECOMMENDATION}

The study's objective was to arrive at the factors that influence the voluntary adoption of IFRS in small and medium firms in Vietnam, such as legitimacy, dependence, consistency, time, international trade, uncertainty, operational risk, financial risk, industry, and flexibility. We employed a quantitative technique known as logit regression to examine the effects. Research hypotheses and models based on the research of Guerreiro et al. (2012) as well as Phan (2014) were developed. The literature review, research model development, concept measurement, data gathering, and model testing were all steps in the research process. The majority of factors, except for flexibility, have a positive influence on the voluntary use of IFRS.

In terms of theoretical contribution, the findings are consistent with several previous studies (Guerreiro et al., 2012, Mantzari et al., 2017; Albu et al., 2020), with the exception that flexibility has a negative influence on the voluntary use of IFRS due to the relatively substantial inertia associated with changing a departmental system. The findings of this study add to a better understanding of this issue from the perspective of developing country contribution and institutional variations.

In terms of practical contribution, because Vietnam is one of the few nations that has not yet 
adopted IFRS, research in this area can assist businesses in identifying the factors that affect IFRS adoption, as well as applying IFRS to improve company image. For government bodies, the study aids in forecasting the various aspects that influence policy adoption and directing IFRS implementation.

The use of IFRS in Vietnam necessitates a detailed plan to ensure that the standard is adopted in accordance with local conditions. As a result, this is not solely the responsibility of the government; the cooperation of nongovernmental economic organizations also is necessary. In addition, authorities, professional vocations, and businesses must prepare conditions for using the new norm.

The State should build a legal pathway with an appropriate mechanism to minimize the difficulties enterprises face in the transition to the application of the new set of standards. Specifically, businesses that actively apply IFRS to prepare financial statements will have priority for loans or access to capital sources at lower costs. To pursue a legitimacy image, the function of government needs to support professional organizations in terms of expertise and resources such as the Vietnam Association of Accountants and Auditors to perform their missions well. By increasing the organization of periodic seminars, applying information technology such as developing applications on mobile platforms to disseminate research results and updated content as well as innovations in the field of information technology, firms get more official information.

Firms also need to coordinate with the government when adopting technology, participating in forums of official professional organizations to update new content, and apply for accounting work. These actions increase the reputation of the business through an image of being a leader in complying with new regulations, enhance the legitimacy of the business and help gain social recognition. The survey results show that the majority of people working as accountants in enterprises find it difficult to transition to new regulations. Therefore, enterprises need to create conditions for the employees involved in the preparation of financial statements, especially accounting staff, to improve their understanding of IFRS.
Limitations of the study are that the available samples are small and the survey questionnaires were sent through internet sources, so accuracy and complete understanding of the subjects cannot be considered controlled research. Although the survey subjects have high professional qualifications and accounting knowledge, the understanding of IFRS is still lacking because this set of standards has not been widely disseminated in Vietnam.

\section{ACKNOWLEDGMENT}

This research is funded by the University of Economics Ho Chi Minh City, Vietnam.

\section{REFERENCES}

Abor, J., \& Biekpe, N. (2006). SMEs' access to debt finance: A comparison of male-owned and female-owned businesses in Ghana. The International Journal of Entrepreneurship and Innovation, 72), 105-112. https://doi.org/10.5367/0000000067769286 27

Albu, C. N., Albu, N., \& Alexander, D. (2014). When global accounting standards meet the local context-Insights from an emerging economy. Critical Perspectives on Accounting, 25(6), 489-510. https://doi.org/10.1016/j.cpa.2013.03.005

Albu, N., Albu, C. N., \& Gray, S. J. (2020,). Institutional factors and the impact of international financial reporting standards: the Central and Eastern European experience. In Accounting Forum, 44(3), 184-214, https://doi.org/10.1080/01559982.2019.170 1793.

Bassemir, M., \& Novotny-Farkas, Z. (2018). IFRS adoption, reporting incentives and financial reporting quality in private firms. Journal of Business Finance \& Accounting, 45(7-8), 759-796. https://doi.org/10.1111/jbfa.12315

Dandago, K. I., \& Hassan, N. I. B. (2013). Decision usefulness approach to financial reporting: A case for Malaysian Inland Revenue Board. Asian Economic and Financial Review, 3(6), 772. http://www.aessweb.com/pdffiles/aefr\%203(6)\%20772-784.pdf 
De Luca, F., \& Prather-Kinsey, J. (2018). Legitimacy theory may explain the failure of global adoption of IFRS: the case of Europe and the US. Journal of Management and Governance, 22(3), 501-534. https://doi.org/10.1007/s10997-018-9409-9

Dillard, J. F., Rigsby, J. T., \& Goodman, C. (2004). The making and remaking of organization context. Accounting, Auditing \& Accountability Journal, 17 (4), 506-542 https://doi.org/10.1108/09513570410554542

Goodstein, J. D. (1994). Institutional pressures and strategic responsiveness: Employer involvement in work-family issues. Academy of Management journal, 372), 350-382. https://doi.org/10.2307/256833

Gordon, L. A., \& Narayanan, V. K. (1984). Management accounting systems, perceived environmental uncertainty and organization structure: an empirical investigation. Accounting, organizations and society, $9(1), 33-47$. https://doi.org/10.1016/03613682(84)90028-X

Guerreiro, M. S., Lima Rodrigues, L., \& Craig, R. (2021). Institutional theory and IFRS: an agenda for future research. Spanish Journal of Finance and Accounting/Revista Española de Financiación y Contabilidad, 50(1), 65-88. https://doi.org/10.1080/02102412.2020.171 2877

Guerreiro, M. S., Rodrigues, L. L., \& Craig, R. (2012). Voluntary adoption of International Financial Reporting Standards by large unlisted companies in Portugal-Institutional logics and strategic responses. Accounting, Organizations and Society, 377), 482-499. https://doi.org/10.1016/j.aos.2012.05.003

Han, X. (2020). Risk management, legitimacy, and the overseas subsidiary performance of emerging market MNEs. International Business Review, 101732. https://doi.org/10.1016/j.ibusrev.2020.1017 32

Hitz, J. M. (2007). The decision usefulness of fair value accounting-a theoretical perspective. European accounting review, 16(2), 323-362. https://doi.org/10.1080/09638180701390974
Le, V. N. T. \& Hoang, T. H.. (2017). Formal accounting harmonization-A new measurement scheme demonstrated by Vietnam's data and International Financial Reporting Standards. HCMCOUJSECONOMICS AND BUSINESS ADMINISTRATION, 7(1). DOI:10.46223/HCMCOUJS.econ.en.7.1.195.2 017

Mantzari, E., Sigalas, C., \& Hines, T. (2017). Adoption of the International Financial Reporting Standards by Greek non-listed companies: The role of coercive and hegemonic pressures. In Accounting Forum (Vol. 41, No. 3, pp. 185-205). https://doi.org/10.1016/j.accfor.2017.04.003

Meyer, J. W., \& Rowan, B. (1977). Institutionalized organizations: Formal structure as myth and ceremony. American journal of sociology, 83(2), 340-363. https://www.jstor.org/stable/2778293

Odia, J. O. (2016). The determinants and Financial Statement effects of IFRS adoption in Nigeria. In Economics and political implications of International Financial Reporting Standards (pp. 319-341). IGI Global. DOI: 10.4018/978-1-4666-98765.ch016

Oliver, C. (1991). Strategic responses to institutional processes. Academy of management review, 161), 145-179. https://doi.org/10.5465/amr.1991.4279002

Palmer, D. A., Jennings, P. D., \& Zhou, X. (1993). Late adoption of the multidivisional form by large US corporations: Institutional, political, and economic accounts. Administrative science quarterly, 100-131. https://doi.org/10.2307/2393256

Phan, D. H. T. (2014). What factors are perceived to influence consideration of IFRS adoption by Vietnamese policymakers?. Journal of Contemporary Issues in Business and Government, The, 201), 27-40. DOI:10.7790/cibg.v20i1.18

Phan, D., Joshi, M., and Mascitelli, B. (2018). What influences the willingness of Vietnamese accountants to adopt International Financial Reporting Standards (IFRS) by 2025. Asian Review of Accounting, 
26(2), 225-247.

https://doi.org/10.1108/ARA-03-2017-0052

Radomska, J. (2014). Operational risk associated with the strategy

implementation. Management, 18(2), 31.

DOI:10.2478/manment-2014-0040

Scott, W. R. (2004). Institutional theory. Encyclopedia of social theory, 11, 408-414.

Svensson, G., \& Saga, A. (2015). Choice of accounting framework from a stakeholder and disclosure perspective. Master thesis. https://lup.lub.lu.se/luur/download?func=do wnloadFile\&recordOId=7870432\&fileOId=78 70433

Tokar, M. (2005). Convergence and the implementation of a single set of global standards: the real-life challenge. Accounting in Europe, 2(1), 47-68.

https://doi.org/10.1080/09638180500379079

Zelinschi D, Levant Y, Berland N. (2012).

Motivations for decoupling. The case of first application of IFRS 8. In: The Interdisciplinary Perspectives on Accounting Conference 2012. July 11-13, Cardiff, UK. 
Appendix 1: Summary of how to measure concepts

\begin{tabular}{|c|c|c|}
\hline Items & Code & Source \\
\hline Legitimacy & LEGITIMACY & \multirow{5}{*}{$\begin{array}{l}\text { Phan, Joshi and } \\
\text { Mascitelli (2018) }\end{array}$} \\
\hline Follow successful IFRS adopters & LEGITIMACY1 & \\
\hline Raise finance overseas & LEGITIMACY2 & \\
\hline Enhance stock market & LEGITIMACY3 & \\
\hline Enhance national reputation & LEGITIMACY4 & \\
\hline Dependence & DEPENDENCE & \multirow{4}{*}{$\begin{array}{l}\text { Guerreiro et al. } \\
\text { (2012) }\end{array}$} \\
\hline $\begin{array}{l}\text { If a company is a subsidiary of a multinational corporation, } \\
\text { it is given a } 1 \text {; otherwise, it is given a } 0 .\end{array}$ & DEPENDENCE & \\
\hline Consistency & CONSISTENCY & \\
\hline $\begin{array}{l}\text { If the parent company is listed, } 1 \text { is displayed; otherwise, } 0 \\
\text { is displayed. }\end{array}$ & TNQ1 & \\
\hline ( & TIME & \multirow{14}{*}{$\begin{array}{l}\text { Phan, D. H. T. } \\
\text { (2014) }\end{array}$} \\
\hline $\begin{array}{l}\text { How much time do you need to prepare for a full transition } \\
\text { to IAS/IFRS? }\end{array}$ & TIME1 & \\
\hline $\begin{array}{l}\text { How long does it take to make the whole transition to } \\
\text { IAS/IFRS? }\end{array}$ & TIME2 & \\
\hline Flexibility & FLEXIBILITY & \\
\hline Updating the data information system. & FLEXIBILITY1 & \\
\hline Updating the accounting process. & FLEXIBILITY 2 & \\
\hline Updating the audit process. & FLEXIBILITY 3 & \\
\hline $\begin{array}{l}\text { Managing the public's perception of financial statement } \\
\text { revisions. }\end{array}$ & FLEXIBILITY 4 & \\
\hline $\begin{array}{l}\text { The management of conversion workloads in while } \\
\text { maintaining daily activities. }\end{array}$ & FLEXIBILITY 5 & \\
\hline $\begin{array}{l}\text { The training of non-specialist staff/management level } \\
\text { accouting financial. }\end{array}$ & FLEXIBILITY 6 & \\
\hline $\begin{array}{l}\text { The training of staff/managers in the finance department, } \\
\text { accounting department. }\end{array}$ & FLEXIBILITY 7 & \\
\hline $\begin{array}{l}\text { Incomplete guidance on first application of IAS/IFRS } \\
\text { (according to IFRS1). }\end{array}$ & FLEXIBILITY 8 & \\
\hline The Vietnamese translations of IAS/IFRS are not timely. & FLEXIBILITY 9 & \\
\hline $\begin{array}{l}\text { Accounting curricula at universities have little mention of } \\
\text { IAS/IFRS. }\end{array}$ & FLEXIBILITY10 & \\
\hline International Trade & TRADE & \multirow{4}{*}{$\begin{array}{l}\text { Svensson and } \\
\text { Saga (2015) }\end{array}$} \\
\hline $\begin{array}{l}\text { Estimate the percentage of the group's sales that are } \\
\text { exported }\end{array}$ & TRADE1 & \\
\hline $\begin{array}{l}\text { Estimate the percentage of the groups purchase that are } \\
\text { imported }\end{array}$ & TRADE2 & \\
\hline $\begin{array}{l}\text { The choice of framework was impacted by the } \\
\text { international trading partner's information demands }\end{array}$ & TRADE3 & \\
\hline
\end{tabular}


Appendix 1: Continued

\begin{tabular}{|c|c|c|}
\hline Uncertainty & UNCERTAINTY & \multirow{8}{*}{$\begin{array}{l}\text { Gordon and } \\
\text { Narayanan } \\
(1984)\end{array}$} \\
\hline How intense is each of the following in your industry? & UNCERTAINTY1 & \\
\hline $\begin{array}{l}\text { How many new products and/or services have been } \\
\text { marketed during the past } 5 \text { years by your industry? }\end{array}$ & UNCERTAINTY2 & \\
\hline $\begin{array}{l}\text { How stable/dynamic is the external environment } \\
\text { (economic and technological) facing your firms? }\end{array}$ & UNCERTAINTY3 & \\
\hline $\begin{array}{l}\text { How would you classify the market activities of your } \\
\text { competitors during the past } 5 \text { years? }\end{array}$ & UNCERTAINTY4 & \\
\hline $\begin{array}{l}\text { During the past } 5 \text { years, the tastes and preferences of your } \\
\text { customers have become. }\end{array}$ & UNCERTAINTY5 & \\
\hline $\begin{array}{l}\text { During the past } 5 \text { years, the legal, political and economic } \\
\text { constraints surrounding your firm have. }\end{array}$ & UNCERTAINTY6 & \\
\hline $\begin{array}{l}\text { How often do new scientific discoveries emerge in your } \\
\text { industry? }\end{array}$ & UNCERTAINTY7 & \\
\hline Operational Risks & OR & \multirow{5}{*}{$\begin{array}{l}\text { Radomska } \\
(2014)\end{array}$} \\
\hline $\begin{array}{l}\text { Environment - rapidly changing environment forces } \\
\text { frequent modification of the strategy implemented }\end{array}$ & OR1 & \\
\hline $\begin{array}{l}\text { People - the resistance of employees to changes associated } \\
\text { with the strategy implementation }\end{array}$ & OR2 & \\
\hline $\begin{array}{l}\text { Internal processes - regular measurement of progress in } \\
\text { the implementation work }\end{array}$ & OR3 & \\
\hline $\begin{array}{l}\text { Systems - appointment of a person or a special team } \\
\text { responsible for supervising and coordinating the strategy } \\
\text { implementation process (supervision system) }\end{array}$ & OR4 & \\
\hline Financial Risks & FR & \multirow{9}{*}{$\begin{array}{l}\text { Abor and Biekpe } \\
\text { (2006) }\end{array}$} \\
\hline Lack of securable assets & FR1 & \\
\hline Lack of knowledge by finance providers about my business & FR2 & \\
\hline Do not meet eligibility criteria & FR3 & \\
\hline $\begin{array}{l}\text { Lack of knowledge by my business about lending criteria } \\
\text { used by providers }\end{array}$ & FR4 & \\
\hline Difficulty in finding out about available finance & FR5 & \\
\hline Bureaucracy & FR6 & \\
\hline Lack of financial performance track record & FR7 & \\
\hline High Interest & FR8 & \\
\hline Industry & Industry & \multirow{4}{*}{$\begin{array}{l}\text { Svensson and } \\
\text { Saga }(2015)\end{array}$} \\
\hline $\begin{array}{l}\text { A majority of the groups is active within the following } \\
\text { industry ( Material, Finance and Insurance, Industry goods } \\
\text { Transport and aviation, Telecom and IT, Healthcare, } \\
\text { Consumer goods, Energy, Construction and Property, } \\
\text { Investment company) }\end{array}$ & INDUSTRY1 & \\
\hline $\begin{array}{l}\text { The choice of the framework was impacted by the industry } \\
\text { competitors' choice of framework }\end{array}$ & INDUSTRY2 & \\
\hline $\begin{array}{l}\text { The choice of the framework was impacted by industry- } \\
\text { specific information demands }\end{array}$ & INDUSTRY3 & \\
\hline Voluntary adoption IFRS & IFRS & \multirow[t]{2}{*}{$\begin{array}{l}\text { Guerreiro et al. } \\
(2012)\end{array}$} \\
\hline $\begin{array}{l}\text { Companies that are ready to adopt IFRS in the future are } \\
\text { given a value of one, whereas companies that use the } \\
\text { national accounting system are given a value of zero. }\end{array}$ & & \\
\hline
\end{tabular}




\section{ABOUT THE AUTHORS}

Nguyen Xuan Hung, email: Hungnx@ueh.edu.vn

Dr. Trinh Hiep Thien is a lecturer in School of Accounting, University of Economics Ho Chi Minh City. He teachess and performs research in the field of management accounting, financial accounting.

Assoc. Prof. Dr. Nguyen Xuan Hung is a lecturer in School of Accounting, University of Economics Ho Chi Minh City. Nguyen Xuan Hung is Doctor in (Economics) from the School of Accounting of University of Economics Ho Chi Minh City, Vietnam and Associate Professor in Accounting at School of Accounting of University of Economics Ho Chi Minh City. She works in the field of financial accounting. She has many publications in the national and international journals. She has participated in many national and international conferences. 